\title{
The Impact of Population Ageing and Social Stratification: The Case of Latvia
}

\author{
Submitted 13/11/18, $1^{\text {st }}$ revision 21/12/18, $2^{\text {nd }}$ revision 5/1/19, accepted 5/2/19 \\ R. Rupeika-Apoga ${ }^{1}$, I. Romānova ${ }^{2}$, L. Bule ${ }^{3}$, Y.E. Thalassinos ${ }^{4}$
}

\begin{abstract}
:
Population ageing and social stratification is widely assumed to have detrimental effects on the economy yet there is little empirical evidence about the magnitude of its effects.

The aim of this article is to investigate the relationships between population ageing and social stratification and the state of economy of a small and post-transition economy. We are looking for these relationships and their strength of influence; at what time after shocking these variables reach their original levels.

We apply standard Granger (non-) causality tests, VAR (Vector Auto-Regressive), IRF (Impulse Response Function) and the prediction error variance analysis by using quarterly data from 2000 to 2018.
\end{abstract}

Research results show that the changes in the level of GDP per capita and the number of pensions paid imply changes in the number of retired persons. The research results have important contribute to policy debates about the impact of population ageing and social stratification on the state of economy in small and post-transition economy.

Keywords: Population ageing, population social stratification, post-transition economy, small and open economy.

Acknowledgments: The paper was supported by the project "INTERFRAME-LV"

\footnotetext{
${ }^{1}$ University of Latvia, e-mail: $\underline{\text { rr@lu.lv }}$

${ }^{2}$ University of Latvia, e-mail: inna.romanova@lu.lv

${ }^{3}$ University of Latvia, e-mail: larisa.bule@lu.lv

${ }^{4}$ GUST of Kuwait, e-mail: thalassinos@hotmail.com
} 


\section{Introduction}

Despite the increasing amount of literature on population ageing and social stratification there is still no clear consensus on their impact on the economy. What are the implications of an ageing population and social stratification? An older population presents many challenges to labour markets, government tax, government spending and the wider economy. Much of the macroeconomic literature on population ageing and social stratification or differences concerns the impact on economic growth, investment, productivity growth, employment, stability and income distribution. Most of the literature has assessed the impact of population ageing and social stratification on advanced economies and some on developing countries. However, there is gap of contributions focus on the peculiar features of population ageing and social stratification in small and post-transition economies. The literature on population ageing and social stratification in small and post-transition economies is relatively new, and to the best of the authors' knowledge, it has never been defined and has not (yet) developed into a scientific field by itself, with systematic research and rigorous theoretical frameworks.

The aim of this article is to investigate the relationships between population ageing and social stratification and the state of economy of a small and post-transition economy. An increasing amount of research focuses on exploring the linkage between an ageing population and social differences or inequality; population ageing and economic growth, separately, but we are looking for the relationships between population ageing, social stratification and the state of economy, their strength of influence; at what time after shocking these variables reach their original levels.

Due to the limited scope of this study, we focus on the presentation of population ageing and social stratification in the perspective of the retired persons. Based on the literature review to investigate the relationships between population ageing and social stratification and the state of economy we used such variables as:

- GDP per capita in constant (2016Q4) prices as a proxy of the state of economy (Y);

- The number of pensioners per 1000 inhabitants as a proxy of population ageing (PA);

- Average monthly number of old-age pensions paid in constant (2016Q4) prices as proxy of social stratification (PS).

The average old-age pension (PS) in Latvia is a number which must be looked at in the light of some particularities of the Latvian pension system. Since there is no ceiling for pensions, there are some who receive large pensions and at the same time a large majority of the retired population receive a very small pension and most pensions are below the average rate. Overall, this shows the remarkable level of inequality in the pension system and how it contributes to the overall level of social inequality in the country. In addition, pensions in Latvia are small because the 'pension floor' 
(minimum pension) is dependent on the individual's work record, and the pension rates for less than 41 years of work are relatively low.

The research period covers years from 2000(Q1) till 2018(Q3), including such important event for Latvia as the joining of the EU in 2004, the global financial crisis in 2008/09 and introduction of the euro in 2014. We put forward such hypotheses:

- H1: Change of population ageing implies significant changes in the state of economy or/and vice versa;

- H2: Change of social stratification implies significant changes in the state of economy or/and vice versa;

- H3: Population ageing is significantly responsive to social stratification or/and vice versa.

We investigate the relationships between population ageing and social stratification and economy applying standard VAR and Granger (non-)causality tests, IRF (Impulse Response Function) and the prediction error variance analysis by using quarterly data. The empirical results indicate that the changes in the level of GDP per capita and the number of pensions paid imply changes in the number of retired persons.

The findings of this study provide useful insights for policy makers, regulators, practitioners, researches and stakeholders. The main contribution is the analysis of population ageing and social stratification impact on post-transition economy which is the major concern of the regulators in their pursuit of economic development.

The first section analyses the conceptual issues about population ageing and social stratification and its impact on the economy. The second section deals with the investigation of the relationships between population ageing and social stratification and the state of economy and their strength of influence; at what time after shocking these variables reach their original levels. In this chapter methodological approach, sample, data collection and research model are discussed. The third section concludes by providing a systematic overview of the considered themes.

\section{Literature review}

As the populations of developed countries become older than ever before, a persistent question has been what impact will this unprecedented demographic change have on the state of economy? Many economists took up the study of the correlation between the population ageing and economic growth, wondering what the cause is and what is the effect. Maestas et al. (2016) use predicted variation in the rate of population ageing across U.S. states over the period 1980-2010 to estimate the economic impact of ageing on state output per capita. They find that a $10 \%$ increase in the fraction of the population ages $60+$ decreases the growth rate of GDP per capita by $5.5 \%$. The economists Acemoglu and Restrepo (2017) look at the relationship between an ageing population and aggregate economic growth. After running several regressions analyses that account for initial GDP levels, they found that there isn't a negative 
relationship between an older population and GDP growth. In fact, some of the results indicate a positive relationship between ageing and economic growth, though this relationship is weaker when they look at only high-income countries of the OECD.

Another area gaining attention, is the impact that population ageing will have on the financial security of the world's ageing population. Of importance is whether the ageing, and soon to be aged populations, are adequately preparing for old age. Further, this will have serious global implications both economically and socially, not the least of which are reduced levels of global GDP growth and increased demands on already fragile social safety nets (Čihák et al., 2016, Rupeika-Apoga et al., 2018, Dabla-Norris et al., 2015, Sahay et al., 2015).

To address the financial challenges of population ageing, nearly every country globally has already taken, or is beginning to take, a serious look at the sustainability of existing pension systems (Allianz, 2014). Policy makers in some countries have already begun the process of pension system reform, however, the growing numbers and proportions of older persons will make it difficult for these programs to provide and maintain adequate income support into the future. Moreover, younger cohorts in many countries are not large enough to fund these programs far into the future. Lyons, et al. (2018) state that there are considerable differences between the OECD and nonOECD countries in terms of the adequacy and sustainability of their public pension systems and other key macroeconomics indicators of old-age security. These differences are likely contributing to the economic and financial difficulties nonOECD countries are facing when attempting to provide a basic level of income security in old age for all citizens.

Strictly quantitative economic variables are more useful to describing social stratification than explaining how social stratification is constituted or maintained. Income is the most common variable used to describe stratification and associated economic inequality in a society (Grusky \& Takata, 1992). Economic inequalities exist both between older persons and the rest of the population and among older persons themselves, leaving many excluded from prosperity, resources and decent work. Economists generally focus on economic disparity in three metrics: wealth, income, and consumption. The issue of economic inequality is relevant to notions of equity, equality of outcome, and equality of opportunity. Economic inequality is sometimes called income inequality, wealth inequality, or the wealth gap. According to Department of Economic and Social Affairs programme on ageing only a minority of the global population accumulates enough savings and other assets to provide for their own economic security in old age. Many older persons work until they are no longer able to or until they are legally required to retire, and rely on family support and on pensions, where they are available (UNDESA, 2016).

While the literature has widely studied ageing-induced changes to economic growth (Marešová et al., 2015; Maestas et al., 2016, Čihák et al., 2016, Dabla-Norris et al., 2015); ageing and inequlity (Atalay \& Barrett, 2015, UNDESA, 2016, Olivera et al., 
2018), the relationships between ageing and social stratification and the state of economy is less understood, especially in small and post-transition economies.

After the collapse of the Soviet Union in 1991 Latvia inherited the old Soviet Union social security system, which was characterized by low retirement age ( 55 for women, 60 for men), high income replacement rates (ranging from $50-100 \%$ of previous monthly income) and financing of pension expenditures directly from state budget (Volskis, 2012). The pension reform process in Latvia began soon after the reestablishment of national independence. The reform of 1991 involved the approval of a new pension law and the introduction of a social tax that constituted $38 \%$ of earnings ( $37 \%$ paid by the employer, $1 \%$ by the employee) (OECD, 2004). In 1995, Latvia became the first country in Central and Eastern Europe to implement parametric reform of the Soviet-style PAYGO pension system, and the first in the world to implement the "notional defined contribution system" (NDC), which was based on labor market remuneration growth factors, capital saving and individual contribution principles.

However, growing risks of low fertility rates, ageing of population and migration working age population have pushed to develop new pension system reforms. As a result, the retirement age is being gradually increased (a process which began in 2014) by three months per year until 2025 when it will reach 65 years. In 2018 the retirement age was 63 years and three months, meaning that in January 2019 it has already increased to 63 years and 6 months. Even Latvia has joined the OECD countries club in 2016, due to the historical background of the former Soviet Union country, its income inequality is high compared to other OECD countries. The Gini coefficient, which takes values between 0 (most equal) and 1 (most unequal), stood at 0.35 in 2016 , compared to the OECD average of 0.32 . The average income of the top $20 \%$ of income earners is 6.4 times higher than that of the bottom $20 \%$, compared to an average ratio of 5.4 in OECD counties. One specific feature behind the high level of inequality in Latvia is the very small size of the middle class. The incidence of poverty - the share of people living with less than half the median income - is high too, at $16 \%$. This is higher than in any other European OECD country and significantly exceeds the OECD average of $12 \%$. Poverty incidence is especially high among older adults: $27 \%$ of people aged above 65 are poor in Latvia, compared to $13 \%$ in OECD on average. This is the second highest value in the OECD (OECD, 2019).

Galbraith (2017) argues that countries with larger financial sectors have greater inequality, and the link is not an accident. Financialization degree measured by banking assets as percentage of GDP in Latvia for many years was the highest ratio comparing to the other Baltic States, so in 2015 it was $117 \%$ in Latvia, while $112 \%$ and $63 \%$ in Estonia and Lithuania respectively. Availability of banks' loans to older persons in Latvia is limited as they are considered more risky comparing with younger ones, what results with higher interest rates and shorter period for mortgage loans. Additionally, the banking industry is going through digital changes: new devices, technologies and FinTech are changing the banking business models. The smartphone 
is the main choice for the banks' customers of today. New banks are operating digitalonly models and giving to their customers a full range of banking services in smartphone. Customers increasingly expect to follow up with bank staff through digital chat, video or other real-time options and banks actively develop them (Japparova \& Rupeika-Apoga, 2017). Nevertheless, if this process is most welcome within young generation, then the oldest ones are suffering from decrease of on-site availability.

\section{Sample and Data}

One of the most important issues in assessing the relationship between population ageing and social stratification and economy is how to obtain the satisfactory empirical measures. Based on literature review we include in our analysis the system which consists of three variables:

- GDP per capita in constant (2016Q4) prices (Y); this variable reflects the general state of the economy and wellbeing of nation (Mhadhbi 2014; Estrada et al., 2011; Hristova et al., 2016; Nyce \& Schieber, 2005);

- The number of pensioners per 1000 inhabitants (PA) as a proxy of population ageing (Sanderson \& Scherbov, 2013; Estrada et al., 2011);

- Average monthly number of old-age pensions paid in constant (2016Q4) prices (PS) as a proxy of social stratification (Grusky \& Takata, 1992; Oris et al., 2017).

This approach looks at population ageing and social stratification from both the output and input sides of the economic process, as the value of pensions paid measures economic output, the number of pensioners per 1000 inhabitants represents the input, while GDP per capita represents the general state of economy and serves as a barometer of nation wellbeing.

The database consists of 75 quarterly observations, from 2000Q1 to 2018Q3. The original data are obtained from the Eurostat data base and Statistical Office of Latvia with following authors own calculations to obtain research variables. The time series of three variables are presented in Figure 1.

During analysed period the growth of the economy, nation wellbeing and the pensions paid were positive excluding the $2008 / 09$ crisis period, meanwhile number of retired persons per 1000 inhabitants was declining until the crisis with sharp increase till 2011/12, that was caused by the last global financial crisis, pushing the retirement age persons to retire and stabilising during the last years.

We also include dummy variables in the analysis: three seasonal dummies, EU dummy to observe the effects connected with access of Latvia into the European Union (1 since the second quarter of 2004, 0 otherwise), the FC dummy for financial crisis period (from 2008Q4 until 2010Q4) and the CR dummy for period of time when the euro is the official currency in Latvia (from 2014Q1 until 2018Q3). 
Figure 1. The time series of GDP per capita in constant (2016Q4) prices, USD (Y), average monthly number of old-age pensions paid in constant (2016Q4) prices, USD (PS) and the number of pensioners per 1000 inhabitants (PA) from 2000 till $2018 Q 3$.
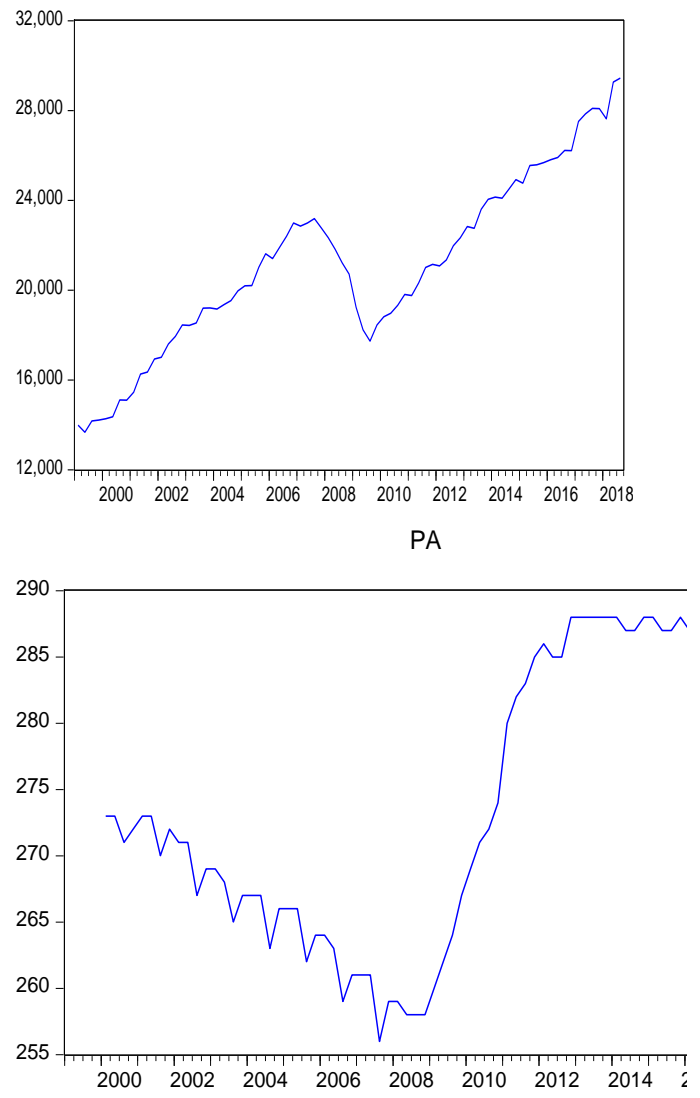

PS

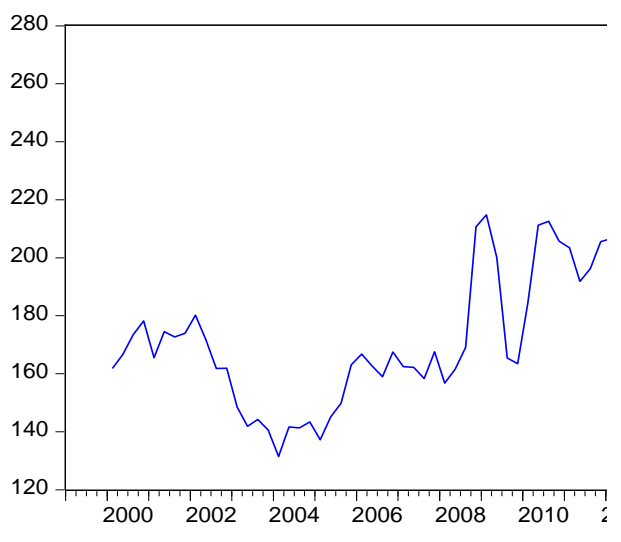

Source: own calculations.

\section{Econometric Methodology}

We investigate the relationships between population ageing, social stratification and the state of economy applying standard VAR, the choice of research method is based on the literature review (Wong, 2014; Loparite, \& Mauro, 2017).

First, we consider stationarity of all variables and consider possibility of cointegration with an Engle-Granger and Johansen procedures. After that, we consider Grangercausalities between differenced variables. At the end, we check optimal number of lags and estimate VAR model with dummy variables, analyze impulse response functions and variance decomposition. The VAR models are multi-equation models developed by C. Sims, in which each variable is explained by its delays and by delays in other explanatory variables. The relationships between individual equations in the 
VAR model are only evident in the relationships between the random components of these equations. VAR models are usually utilized to create forecasts, to study relationships between variables, to test the general economic theory, and to carry out multiplication analyses and cointegration studies (Kusideł, 2000).

Before estimating the VAR model, several assumptions must be fulfilled. A stable VAR needs variable to be stationary, i.e. the first and second moments of them are time invariant. To confirm the integration order of analysed variables we performed both ADF (with trend and constant, with constant and without trend and constant) and KPSS tests. In the ADF we test number of lags until 10 lags, and in the KPSS test we use 3 lags. The results, shown in Table 1, confirm, that Y and PS are most likely I(1), but their first differences are $\mathrm{I}(0)$. Third variable, PA, turns out to be $\mathrm{I}(2)$, therefore we consider in VAR model its second differences which is a stationary variable.

Table 1. Results of stationarity tests.

\begin{tabular}{|l|l|l|l|l|l|}
\hline & $\begin{array}{l}\text { ADF, trend } \\
\text { and constant }\end{array}$ & ADF, constant & $\begin{array}{l}\text { ADF, without } \\
\text { trend and } \\
\text { constant }\end{array}$ & $\begin{array}{l}\text { KPSS, trend } \\
\text { and constant }\end{array}$ & $\begin{array}{l}\text { KPSS, } \\
\text { constant }\end{array}$ \\
\hline $\mathrm{Y}$ & -1.392484 & -0.451238 & 2.661873 & $0.205512 * * *$ & $1.647690^{* * *}$ \\
\hline $\mathrm{PS}$ & $-3.318739 *$ & 0.039997 & 1.290620 & $0.263412^{* * *}$ & $1.617103 * * *$ \\
\hline $\mathrm{PA}$ & -3.071526 & -1.790806 & 0.237206 & $0.332302 * * *$ & $1.290595 * * *$ \\
\hline $\mathrm{dY}$ & $-6.841810^{* * *}$ & $-6.887872 * * *$ & $-6.020397 * * *$ & 0.139700 & 0.152410 \\
\hline $\mathrm{dPS}$ & $-7.425911^{* * *}$ & $-7.278646 * * *$ & $-7.123565 * * *$ & 0.034403 & 0.099360 \\
\hline $\mathrm{dPA}$ & -1.579297 & -1.587679 & $-1.568683^{*}$ & $0.229544 * * *$ & $0.385564 *$ \\
\hline $\mathrm{d}^{2} \mathrm{PA}$ & $-17.02762 * * *$ & $-17.15221 * * *$ & $-17.28263 * * *$ & 0.085622 & 0.088087 \\
\hline
\end{tabular}

Source: Own calculations, *, **, ***denote significance at 10\%, 5\%, $1 \%$ respectively.

Further, the time series are not allowed to be cointegrated, otherwise VECM should be used. We performed Johansen and Engle-Granger cointegration tests. Both of them show that variables Y, PS and dPA are not cointegrated. Tests results allow us to use standard Vector Auto-Regressive model.

\section{Results and discussion}

We start with a test for optimal number of lags. With 75 observations, 3 variables in the system and 6 dummies the maximum number of lags available in order to have enough degrees of freedom is 4 , therefore we performed tests of optimal lag structure. Tests indicate to use in VAR model three lags (Table 2).

Table 2. Results of the optimal number of lags in the VAR model test.

\begin{tabular}{lllllll}
\hline \hline Lag & LogL & LR & FPE & AIC & SC & HQ \\
\hline \hline 0 & -852.4575 & NA & $1.44 \mathrm{e}+08$ & 27.29555 & 28.00393 & 27.57462 \\
1 & -819.7290 & 55.22943 & 68898371 & 26.55403 & 27.56601 & 26.95270 \\
2 & -806.2163 & 21.53581 & 60404157 & 26.41301 & 27.72858 & 26.93128
\end{tabular}




\begin{tabular}{lllllll}
3 & -781.7657 & $36.67597 *$ & $37845527 *$ & $25.93018^{*}$ & $27.54934 *$ & $26.56805^{*}$ \\
4 & -777.9754 & 5.330089 & 45564271 & 26.09298 & 28.01574 & 26.85045 \\
5 & -774.9119 & 4.020837 & 56649794 & 26.27850 & 28.50485 & 27.15557 \\
6 & -770.6514 & 5.192484 & 68644353 & 26.42661 & 28.95655 & 27.42328 \\
\hline \hline
\end{tabular}

* indicates lag order selected by the criterion

Source: Own calculations.

To check the stationarity of the system the roots of characteristic polynomial were checked and as can be seen from Table 3, all modulus is less than one, no root lies outside the unit circle, that proves that this VAR system satisfies the stability condition.

Table 3. Results of VAR model stationary test: roots of characteristic polynomial

\begin{tabular}{|l|l|}
\hline Root & Modulus \\
\hline-0.845817 & 0.845817 \\
\hline$-0.103231-0.836476 \mathrm{i}$ & 0.842822 \\
\hline$-0.103231+0.836476 \mathrm{i}$ & 0.842822 \\
\hline $0.386513-0.722544 \mathrm{i}$ & 0.819428 \\
\hline $0.386513+0.722544 \mathrm{i}$ & 0.819428 \\
\hline 0.757522 & 0.757522 \\
\hline$-0.421090-0.081498 \mathrm{i}$ & 0.428904 \\
\hline$-0.421090+0.081498 \mathrm{i}$ & 0.428904 \\
\hline-0.147273 & 0.147273 \\
\hline
\end{tabular}

Granger causality test, typically used in a VAR model framework, are a standard analysis technique for determining whether one time series is useful in forecasting another. In the next step we perform Granger causality tests for six pairs of endogenous variables: $d Y$ to $d P S, d Y$ to $d^{2} P A, d P S$ to $d Y, d P S$ to $d^{2} P A, d^{2} P A$ to $d Y$ and $\mathrm{d}^{2} \mathrm{PA}$ to $\mathrm{dPS}$. The Table 4 presents test statistics of these tests.

Table 4. Results of VAR Granger Causality/Block Exogeneity Wald Tests

Dependent variable: DY

\begin{tabular}{llll}
\hline \hline Excluded & Chi-sq & df & Prob. \\
\hline \hline DPS & 3.177142 & 3 & 0.3651 \\
D2PA & 1.803912 & 3 & 0.6141 \\
\hline \hline All & 5.959570 & 6 & 0.4277 \\
\hline \hline
\end{tabular}

Dependent variable: DPS

Excluded Chi-sq $\quad$ df $\quad$ Prob.




\begin{tabular}{llll} 
DY & 0.284144 & 3 & 0.9630 \\
D2PA & 2.650612 & 3 & 0.4487 \\
\hline \hline All & 3.118868 & 6 & 0.7938 \\
\hline
\end{tabular}

Dependent variable: D2PA

\begin{tabular}{llll}
\hline \hline Excluded & Chi-sq & df & Prob. \\
\hline \hline DY & 18.40559 & 3 & 0.0004 \\
DPS & 7.338902 & 3 & 0.0618 \\
\hline \hline All & 26.11839 & 6 & 0.0002 \\
\hline \hline
\end{tabular}

Source: Own calculations.

The Granger causality test shows there is strong causality from dY to $\mathrm{d}^{2} \mathrm{PA}$ (significant at $1 \%$ level) and weak causality between dPS to $\mathrm{d}^{2} \mathrm{PA}$ (significant at $10 \%$ level), other pairs do not show any significance of Granger causality. This means that GDP per capita helps to predict the number of pensioners per 1000 inhabitants, but not vice versa and the average monthly number of old-age pensions paid (euro) helps to predict the number of pensioners per 1000 inhabitants.

Therefore, we decide to estimate VAR model with three lags for all variables and with 3 seasonal dummies, EU dummy, Financial Crisis dummy and the Euro area dummy. We also use robust standard errors. Figure 2 shows impulse response functions and Table 5 contains variance decomposition of all variables in the model. The Cholesky decomposition contains $d Y$ as a first variable, as a second $d^{2} \mathrm{PA}$ and $\mathrm{dPS}$ as a third. Therefore, we claim, that the changes in the level of GDP per capita (Y) and the number of pensions paid (DPS) imply changes in the number of retired persons $\left(d^{2} P A\right)$. As for the impulse analysis it should be pointed out that:

1. the impulse impact on GDP per capita (see Figure 2):

a. from GDP per capita expires shortly after 15 quarters after the shock started;

b. from the number of pensioners expires after more than 10 quarters;

c. from the amount of pension starts to expire after 10 quarters;

2. the impulse impact on the number of pensioners (see Figure 2):

a. from GDP per capita side starts to expire around 20 quarters after the shock started;

b. from the number of pensioners expires after 20 quarters.

c. from the amount of pension side expires shortly after 15 quarters;

3. the impulse impact on the amount of pension (see Figure 2):

a. from GDP per capita shock expires shortly after 15 quarters;

b. from the number of pensioners side shortly after 15 quarters;

c. from the amount of pension shock expires shortly before 20 quarters. 
Figure 2. Impulse response functions
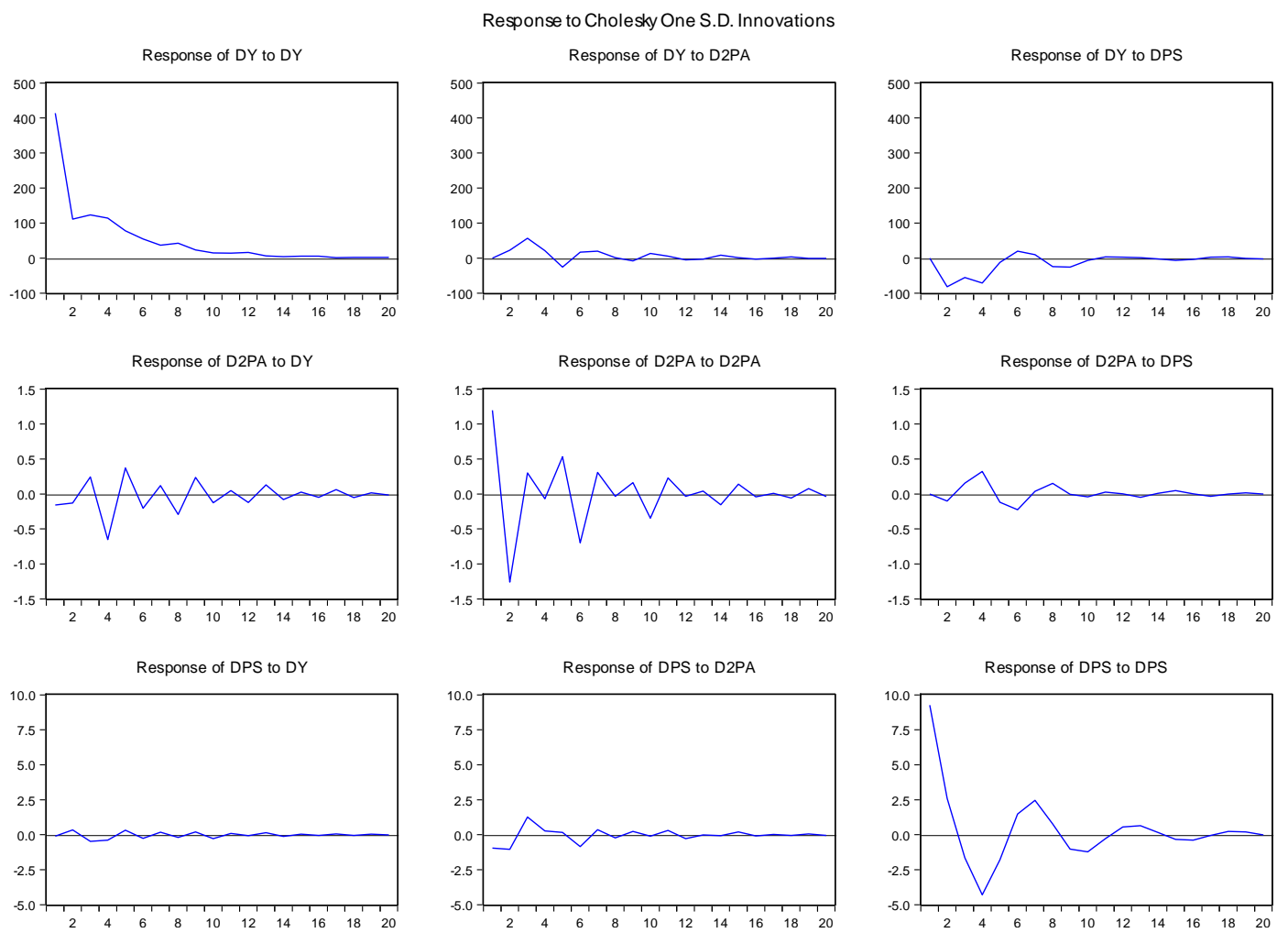

Source: Own calculations.

If the IRF - Impulse Response Function values are convergent, i.e. the impulse is not held indefinitely by variables but is suppressed after several periods, it means that the modeled system is stable and the variables that make it stable are stable. Analyzing the above graphs (Figure 2), we note that for the longest period impulse is maintained for the variable -the number of pensioners to 10000 inhabitants caused by the disruption of the GDP per capita.

The next step was to carry out the prediction error variance analysis. The variance decomposition indicates the amount of information each variable contributes to the other variables in the autoregression. It determines how much of the forecast error variance of each of the variables can be explained by exogenous shocks to the other variables. It tells what share in the explanation of variance of the prediction error of the variable under test have other variables included in the model (see table 5). According to the results presented below the shares of error variance stabilize, in most cases, around 15 quarters. 
Table 5. Results of variance decomposition.

Variance Decomposition of DY:

\begin{tabular}{lllll} 
Period & S.E. & DY & D2PA & DPS \\
\hline \hline 1 & 413.4089 & 100.0000 & 0.000000 & 0.000000 \\
2 & 436.4992 & 96.20539 & 0.259809 & 3.534805 \\
3 & 460.4154 & 93.62556 & 1.745220 & 4.629220 \\
4 & 480.2028 & 91.73959 & 1.796584 & 6.463822 \\
5 & 487.2842 & 91.63205 & 2.026206 & 6.341747 \\
10 & 496.9586 & 90.85719 & 2.318062 & 6.824749 \\
15 & 497.6902 & 90.80296 & 2.364121 & 6.832919 \\
20 & 497.7963 & 90.78168 & 2.372796 & 6.845519 \\
\hline \hline
\end{tabular}

Variance Decomposition of D2PA:

$\begin{array}{llll}\text { Period S.E. DY D2PA } & \text { DPS }\end{array}$

\begin{tabular}{lllll}
\hline \hline 1 & 1.204901 & 1.729679 & 98.27032 & 0.000000 \\
2 & 1.751440 & 1.352393 & 98.30582 & 0.341792 \\
3 & 1.800229 & 3.099236 & 95.84937 & 1.051398 \\
4 & 1.943318 & 13.94983 & 82.38369 & 3.666488 \\
5 & 2.051853 & 15.79435 & 80.57568 & 3.629969 \\
10 & 2.286370 & 16.79817 & 78.80378 & 4.398043 \\
15 & 2.317759 & 17.10503 & 78.51707 & 4.377894 \\
20 & 2.322744 & 17.20579 & 78.40863 & 4.385579 \\
\hline \hline
\end{tabular}

Variance Decomposition of DPS:

\begin{tabular}{lllll} 
Period & S.E. & DY & D2PA & DPS \\
\hline \hline 1 & 9.305244 & 0.013864 & 1.046345 & 98.93979 \\
2 & 9.725902 & 0.136064 & 2.117292 & 97.74664 \\
3 & 9.957538 & 0.363873 & 3.650930 & 95.98520 \\
4 & 10.85919 & 0.436669 & 3.132115 & 96.43122 \\
5 & 11.01229 & 0.507781 & 3.067828 & 96.42439 \\
10 & 11.56971 & 0.646368 & 3.510146 & 95.84349 \\
15 & 11.62180 & 0.676702 & 3.634297 & 95.68900 \\
20 & 11.63330 & 0.683446 & 3.639558 & 95.67700 \\
\hline \hline
\end{tabular}


Source: Own calculations.

Values for the 20th quarter of the forecast horizon - the decomposition of the error variance of the model equations are as follows: the error variance of GDP in per capita is in $91 \%$ dependent on its own values and around $7 \%$ by the number of pensions paid and about $2 \%$ by the number of pensioners. We hadn't found significant influence of population ageing and social stratification on GDP per capita forecast. The error variance of the number of pensions paid is explained by $1 \%$ by GDP per capita, and by $4 \%$ by the number of pensioners. As for the number of pensioners the error variance is explained by $78 \%$ by its own values, $17 \%$ by GDP per capita and by $4 \%$ by the number of pensions paid.

\section{Concluding remarks}

In this paper we have studied the relationships between population ageing, social stratification and the state of economy of a small and transition economy - Latvia from 2000 to 2018. We note, based on the IRF analysis, that impulses caused by variables - GDP per capita, the number of pensioners per 1000 inhabitants and average monthly number of old-age pensions paid - were suppressed over a period of about $15 / 20$ quarters (3,75-5years), which means that the modeled system is stable. Research results show that GDP per capita during the analyzed period effects the number of pensioners in the Granger test sense and according to VAR model, that confirms our H1 hypothesis second part, that change in the state of economy implies significant changes in the population ageing. But we hadn't found the evidence that the number of pensioners has significant effect on GDP per capita.

The empirical results indicate that social stratification proxy has insignificant effect on the GDP per capita of Latvia and vice versa. That means we cannot confirm our $\mathrm{H} 2$ hypothesis that change of social stratification implies significant changes in the state of economy and/or vice versa.

Granger test, IFR analysis and the variance decomposition allow us to use the proxy of social stratification to forecast changes of the number of pensioners (4,4\% for 5 years), but the responsiveness isn't high and can be used only as additional explanatory variable. That means we can confirm our $\mathrm{H} 3$ hypothesis second part that change of social stratification implies some changes in population ageing. We hadn't found prove for significant responsiveness between the proxies of population ageing and social stratification, allowing us to reject $\mathrm{H} 3$ hypothesis first part that population ageing is significantly responsive to social stratification.

Limitation of this research is in restricted number of variables that were used as proxies for population ageing and social stratifications. Further research of this topic 
could be directed to assess the ageing and social stratification process with different variables (for example the life expectancy, average share of consumption in GDP, ratio of people younger than 15 to the working-age population or similar), and additionally to add other post-transition economy countries.

\section{References:}

Acemoglu, D. \& Restrepo, P. 2017. Secular Stagnation? The Effect of Ageing on Economic Growth in the Age of Automation. American Economic Review, American Economic Association, vol. 107(5), 174-179.

Allianz. 2014. Pension Sustainability Index. Allianz International Pension Papers 1/2004, Allianz SE, Munich, Germany.

Atalay, K., Barrett, G.F. 2015. The impact of age pension eligibility age on retirement and program dependence: evidence from an Australian experiment. Rev. Econ. Stat., 97(1), 71-87.

Central Statistical Office data, available at https://www.csp.gov.lv

Cihák, M., Mare, D. \& Melecký, M. 2016. The Nexus of Financial Inclusion and Financial Stability: A Study of Trade-offs and Synergies. IMF Working Paper International Monetary Fund, Washington, D.C.

Dabla-Norris, E., Townsend, Y., Ji, R. \& Unsal, D.F. 2015. Identifying Constraints to Financial Inclusion and their Impact on GDP and Inequality: A Structural Framework for Policy. IMF Working Paper 15/22 International Monetary Fund, Washington, D.C.

Department of Economic and Social Affairs programme on ageing (2016). Available at https://www.un.org/development/desa/ageing/wpcontent/uploads/sites/24/2016/08/Briefing-Paper_Economic-Inequalities_Final.pdf

Estrada, G., Park, D. and Ramayandi, A. 2011. Population Ageing and Aggregate Consumption in Developing Asia. ADB Economics Working Paper Series No. 282. Eurostat data base, available at https://ec.europa.eu/eurostat/data/database.

Galbraith, J. 2012. Inequality and Instability: A Study of the World Economy Just before the Great Crisis. New York: Oxford University Press.

Grusky, D.B. \& Takata, A.A. 1992. Social Stratification. The Encyclopedia of Sociology. Macmillan Publishing Company, 1955-1970.

Hristova, D., Rutherford, A., Anson, J., Luengo-Oroz, M., Mascolo, C. 2016. The International Postal Network and Other Global Flows as Proxies for National Wellbeing. PLoS ONE 11(6): e0155976.

Japparova, I. \& Rupeika-Apoga, R. 2017. Banking business models of the digital future: The Case of Latvia. European Research Studies Journal, 20(3), 864-878.

Kusideł, E. 2000. Modele wektorowo-autoregresyjne VAR. Metodologia i zastosowanie. Absolwent, Łódź.

Lopreite, M., Mauro, M. 2017. The effects of population ageing on health care expenditure: A Bayesian VAR analysis using data from Italy. Health Policy, Volume 121, Issue 6, 663-674.

Lyons, A., Grable, J. \& Joo, S. 2018. A cross-country analysis of population ageing and financial security. The Journal of the Economics of Ageing, Volume 12, 96-117.

Maestas, N., Mullen, K.J. \& Powell, D. 2016. The Effect of Population Ageing on Economic Growth. The Labor Force and Productivity (No. 22452). NBER working paper series.

Marešová, P., Mohelská, H. \& Kuča, K. 2015. Economics Aspects of Ageing Population. 
Procedia Economics and Finance, Volume 23, 534-538.

Mhadhbi, K. 2014. New Proxy of Financial Development and Economic Growth in Medium-Income Countries: A Bootstrap Panel Granger Causality Analysis. American Journal of Applied Mathematics and Statistics, 2(4), 185-192.

Nyce, S. \& Schieber, S. 2005. The Economic Implications of Aging Societies: The Costs of Living Happily Ever After. Cambridge: Cambridge University Press, 396.

OECD. 2014. Pension Reform in the Baltic Countries. At https://www.oecdilibrary.org/finance-and-investment/pension-reform-in-the-balticcountries 9789264021068-en

OECD. 2019. Income inequality (indicator). doi: 10.1787/459aa7f1-en.

Olivera, J., Andreoli, F., Leist, A. \& Chauvel, L. 2018. Inequality in old age cognition across the world. Economics \& Human Biology, 29, 179-188.

Oris, M., Rainer, G., Ritschard, G. and Kliegel, M. 2017. Long Lives and Old Age Poverty: Social stratification and Life-Course Institutionalization in Switzerland. Research in Human Development, 14(1), 68-87, DOI 10.1080/15427609.2016.1268890.

Rupeika-Apoga, R., Zaidi, S.H., Thalassinos, Y.E. \& Thalassinos, E.I. 2018. Bank stability: The Case of Nordic and non-Nordic banks in Latvia. International Journal of Economics and Business Administration, 6(2), 39-55.

Sahay, R., Čihák, M., N'Diaye, P., Barajas, A., Mitra, S., Kyobe, A, Mooi, Y.N., Yousefi, R. 2015. Financial Inclusion: Can it Meet Multiple Macroeconomic Goals? IMF Staff Discussion Note (SDN/15/17), International Monetary Fund, Washington, D.C.

Sanderson, W.C. \& Scherbov, S. 2013. The Characteristics Approach to the Measurement of Population Aging. Population and Development Review, 39, 673-685.

Volskis, E. 2012. Reforms of Baltic States Pension Systems: Challenges and Benefits. available at https://www.ebrd.com/downloads/news/pension-system.pdf

Wong, A. 2014. Population Ageing and the Aggregate Effects of Monetary Policy", MPRA paper, https://mpra.ub.uni-muenchen.de/57096/1/MPRA_paper_57096.pdf 